\section{Enzyme activity in the micropylar region of Melanoxylon brauna Schott seeds during germination under heat stress conditions}

\author{
Marcone Moreira Santos*1 (D) Eduardo Euclydes de Lima e Borges² ${ }^{\text {(D) }}$, Glauciana \\ da Mata Ataíde ${ }^{3}$ iD, Raquel Maria de Oliveira Pires ${ }^{4}$ (D) , Debora Kelli Rocha ${ }^{4}$ iD
}

ABSTRACT: Recent studies indicate that global temperatures will rise substantially in the $21^{\text {st }}$ century, leading to the extinction of several plant species, as plant metabolism and germination are greatly affected by temperature. Melanoxylon brauna, a tree species native to the Atlantic Forest that occurs from northeastern to southeastern Brazil, is one of the many species threatened by global warming. Despite the economic and ecological importance of $M$. brauna, studies investigating the influence of heat stress on seed germination and biochemical responses are still incipient. This study aimed to evaluate enzyme activity in the micropylar region of $M$. brauna seeds during germination under heat stress conditions. Endo$\beta$-mannanase, $\alpha$-galactosidase, polygalacturonase, pectin methylesterase, pectin lyase, total cellulase, 1,3- $\beta$-glucosidase, and 1,4- $\beta$-glucosidase activities were determined in micropyles of seeds imbibed for 24,48 and $72 \mathrm{~h}$ at 25,35 and $45^{\circ} \mathrm{C}$. Seed germination was highest at $25^{\circ} \mathrm{C}$. Endo- $\beta$-mannanase activity was not detected under any of the experimental conditions, but imbibition temperature had a significant effect on the activity of all other enzymes.

Index terms: cell wall, enzyme, germination, temperature.

\section{Atividade enzimática na região micropilar de sementes de Melanoxylon brauna Schott durante a germinação sob estresse térmico}

RESUMO: Estudos recentes indicam alta na temperatura global no decorrer desse século, fato que pode ocasionar a extinção de diversas espécies vegetais, visto que processos como a germinação são influenciados pela temperatura. Dentre as espécies com risco de extinção está a Melanoxylon brauna, árvore nativa da Mata Atlântica de ocorrência nas regiões Nordeste e Sudeste. Mesmo diante de sua importância econômica e ecológica, estudos referentes à germinação em condições de estresse térmico, bem como suas consequências bioquímicas nas diferentes partes das sementes, ainda são incipientes. Diante disso, objetivou-se avaliar a germinação e a atividade enzimática na região micropilar de sementes de $M$. brauna durante a germinação sob estresse térmico. Avaliou-se germinação nas temperaturas de 25,35 e $45^{\circ} \mathrm{C}$. As atividades das enzimas endo- $\beta$-mannanase, $\alpha$ - galactosidase, polygalacturonase, pectinametilesterase, pectinaliase, celulases totais, $\beta$-1,3- e $\beta$-1,4-glucosidases foram avaliadas em micrópilas embebidas por $0,24,48$ e $72 \mathrm{~h}$ a 25,35 e $45^{\circ} \mathrm{C}$. Houve maior germinação a $25^{\circ} \mathrm{C}$. Não foi detectada atividade da enzima endo- $\beta$-mananase em nenhuma das condições avaliadas. A temperatura de embebição influenciou a atividade das demais enzimas.

Termos para indexação: parede celular, enzima, germinação, temperatura.
Journal of Seed Science, v.42, e202042009, 2020

http://dx.doi.org/10.1590/2317$1545 v 42229988$
${ }^{*}$ Corresponding author
E-mail: marconemoreirasantos@
hotmail.com

Received: $10 / 14 / 2019$. Accepted: 1/10/2020.

${ }^{1}$ Departamento de Ciência Florestal, Universidade Federal Rural de Pernambuco, 52171-900 Recife, PE, Brasil.

${ }^{2}$ Departamento de Engenharia Florestal, Universidade Federal de Viçosa, 36570-900 - Viçosa, MG, Brasil.

${ }^{3}$ Departamento de Ciências Agrárias, Universidade Federal de São João Del-Rei, 36307-352 - São João DelRei, MG, Brasil.

${ }^{4}$ Departamento de Sementes, Universidade Federal de Lavras, 37200-000 - Lavras, MG, Brasil. 


\section{INTRODUCTION}

Melanoxylon brauna Schott is a tree native to the Brazilian Atlantic Forest. It occurs mainly in the southeast and northeast regions of the country. The tree has excellent wood properties, and its bark and sap are widely used in traditional medicine (Lorenzi, 2008). However, because of the overexploitation of its timber, the species is currently classified as vulnerable in the official list of endangered flora of Brazil (Brasil, 2014). Information on seed germination may contribute to the development of conservation strategies for $M$. brauna.

A factor that may greatly affect the conservation status of $M$. brauna is climate change. Studies showed that global temperatures will rise by 1 to $5{ }^{\circ} \mathrm{C}$ over this century (PBMC, 2013). Will the species be able to adapt to the effects of global warming? What can be done to prevent $M$. brauna and other vulnerable tree species from becoming extinct? To answer these questions, it is fundamental to increase the knowledge about the influence of temperature on the different physiological processes involved in seed germination.

Germination is mediated by a series of complex physical, physiological and biochemical processes. To emerge, the radicle must pass through the micropyle. Radicle emergence is preceded by the weakening of the micropylar endosperm and elongation of the embryonic axis (Yan et al., 2014). Although an essential part of seed germination, the mechanisms involved in the rupture of the micropylar endosperm, especially tissue weakening, are still little understood (Nonogaki et al., 2010). Such process is known to involve the loss of cell wall integrity by the action of hydrolases, transglycosylases, cellulases, hemicellulases, and reactive oxygen species (Borges et al., 2015; Koen et al., 2017; Singh et al., 2017). Enzymes activated at the initial stages of imbibition, such as $\beta$-mannanase, $\alpha$-galactosidase $(\alpha-G a l)$, polygalacturonase (PG), pectin methylesterase (PME), pectin lyase (PL) and cellulase, are responsible for the degradation of cell wall polysaccharides and, consequently, the weakening of the micropylar endosperm, contributing to radicle emergence (Betts et al., 2017; Mascher et al., 2017).

Temperature is a major factor influencing enzyme activity during germination. It can decrease, enhance, or even inhibit enzymatic processes and, therefore, accelerate or slow down seed metabolism (Laghmouchi et al., 2017). It may also influence the imbibition rate, altering the speed of chemical reactions that promote the mobilization of reserves and synthesis of necessary compounds for seedling growth. Thus, temperature is a determining factor for the occurrence of a species at a given locality (Medina et al., 2016).

Considering the importance of $M$. brauna, the predictions of climate change, the influence of temperature on germination, and the lack of information about biochemical processes occurring in the micropylar region, this study aimed to assess the activity of endo- $\beta$-mannanase, $\alpha$-Gal, PG, PME, PL, total cellulase, 1,3- $\beta$-glucosidase and $1,4-\beta$-glucosidase in the micropylar endosperm of $M$. brauna seeds during germination under heat stress conditions.

\section{MATERIAL AND METHODS}

\section{Sample harvesting and preparation}

Fruits of M. brauna were harvested in Leopoldina ( $21^{\circ} 31^{\prime} 55^{\prime \prime} \mathrm{S} 42^{\circ} 38^{\prime} 35^{\prime \prime} \mathrm{W}$ ), Minas Gerais, southeastern Brazil, in September 2015. The pods were sun dried, manually threshed, and the seeds cleaned. Empty or damaged seeds and debris were discarded. Healthy, intact seeds were selected and stored in a cold chamber at $5{ }^{\circ} \mathrm{C}$ and $60 \%$ relative humidity until use. The experiments were conducted between February and August 2016. A completely randomized design with five replications of twenty seeds per treatment was used.

\section{Germination test}

Seeds were placed between two sheets of germination paper in petri dishes, moistened with distilled water, and incubated for 24,48 and $72 \mathrm{~h}$ at 25,35 or $45^{\circ} \mathrm{C}$ in BOD incubators. Seeds were considered germinated upon radicle emergence. 
Determination of enzyme activity

Enzyme activity was determined in the micropylar region of dry seeds and seeds imbibed for 24,48 and $72 \mathrm{~h}$ at 25,35 and $45{ }^{\circ} \mathrm{C}$. Micropyles were extracted (Figure 1), subjected to the same conditions as described above, and analyzed for enzyme activity.

Endo- $\beta$-mannanase activity was determined by the gel-diffusion assay of Downie et al. (1994), with modifications. The gel was first washed with distilled water, then incubated with buffer solution for thirty minutes, and washed once more with distilled water. Congo red dye $(0.5 \% \mathrm{w} / \mathrm{v})$ was added, the gel was incubated for thirty minutes, washed with ethanol for ten minutes, and rinsed with distilled water. $\mathrm{NaCl}$ solution $(1 \mathrm{M})$ was added until a white halo was observed where the samples were pipetted.

$\alpha$-Gal activity was quantified according to Borges et al., 2004. One unit of enzyme activity was defined as the amount of protein that releases $1 \mathrm{nmol}$ of $p$-nitrophenol per minute under the assay conditions.

PG activity was determined by the 3,5-dinitrosalicylic acid (DNS) method as adapted by Miller (1959). One unit of PG activity was defined as the amount of protein that produces $1 \mu \mathrm{mol}$ of galacturonic acid per minute of reaction.

PME was extracted according to Pinto et al. (2011), and its activity was quantified according to Grsic-Rausch and Rausch (2004). One unit of PME activity is equivalent to the amount of enzyme required to produce $1 \mu \mathrm{mol}$ of NADPH per minute of reaction at $25^{\circ} \mathrm{C}$ and $\mathrm{pH} 7.5$.

PL activity was determined by the spectrophotometric method of Albersheim and Kilias (1962). Absorbance was read at $235 \mathrm{~nm}$. Enzyme concentration was calculated using a molar absorption coefficient of $5550 \mathrm{~L} \mathrm{~mol}^{-1} \cdot \mathrm{cm}^{-1}$ (Albersheim et al., 1996).

Total cellulase activity was measured by the filter paper assay (Ghose, 1987). A $6 \mathrm{~cm}^{2}$ strip of filter paper was placed in a test tube containing $0.5 \mathrm{~mL}$ of sample (seed incubation solution) and $1.0 \mathrm{~mL}$ of $50 \mathrm{mM}$ sodium acetate buffer $\mathrm{pH}$ 5.0. The reaction was interrupted by the addition of $1 \mathrm{~mL}$ of DNS. The concentration of reducing sugars was determined spectrophotometrically at $540 \mathrm{~nm}$.

$1,3-\beta$-Glucosidase activity was determined using $p$-nitrophenyl $\beta$-D-glucopyranoside as substrate, and $1,4-\beta$-glucosidase activity was determined using carboxymethyl cellulose as substrate. Reactions were conducted in $50 \mathrm{mM}$ phosphate-buffered saline pH 6.0 (Singhania et al., 2013). Enzyme activity was expressed as units per gram of substrate.

Proteins were quantified by the Bradford method (1976) using a standard curve (2.5-50 $\mu \mathrm{g}$ ) of bovine serum albumin.

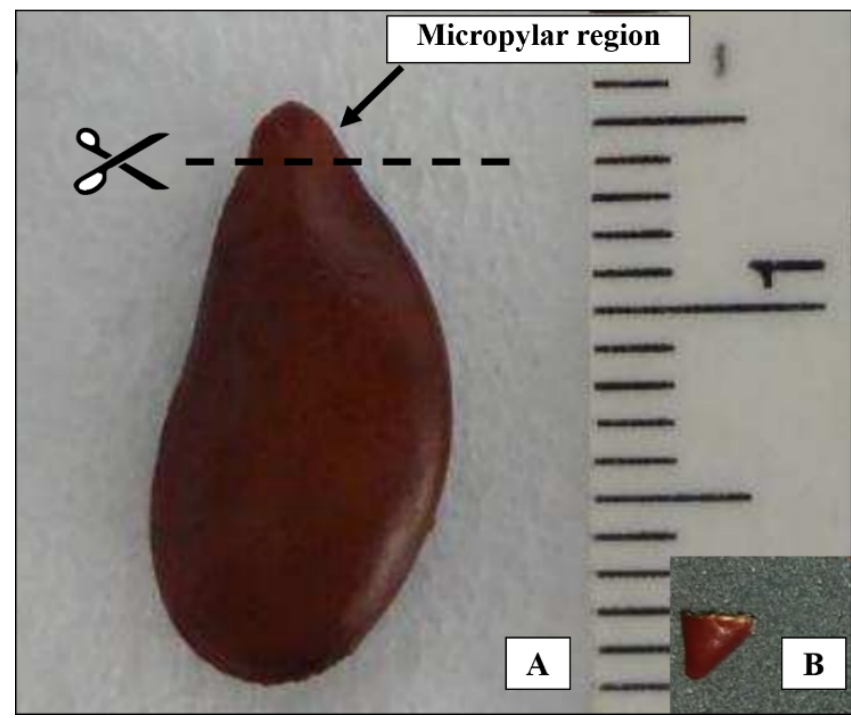

Figure 1. Representative photograph of a Melanoxylon brauna seed (A) and its micropylar region (B). 


\section{Statistical analysis}

Data were subjected to analysis of variance followed by Tukey's test at $p<0.05$. Relationships between enzyme activity and germination conditions were investigated by regression analysis. Statistical analyses were performed using SAS version 9.2 (SAS Institute Inc., Cary, NC, USA).

\section{RESULTS AND DISCUSSION}

Radicle emergence was observed in seeds imbibed for $72 \mathrm{~h}$. Germination was highest (83\%) at $25^{\circ} \mathrm{C}$, decreasing to about $55 \%$ at $35{ }^{\circ} \mathrm{C}$. Imbibition for $72 \mathrm{~h}$ at $45^{\circ} \mathrm{C}$ led to complete loss of seed viability (Table 1). Temperature exerts a great influence on germination, as it regulates water absorption and biochemical reactions involved in seed metabolism (Bewley et al., 2013; Graeber et al., 2014).

In general, seeds of subtropical and tropical species germinate at $20-30{ }^{\circ} \mathrm{C}$ (Oliveira et al., 2016; Silva et al., 2016). The germination behavior of $M$. brauna seeds observed in the current study agrees with that reported in the literature. Flores et al. (2014) found that $M$. brauna seeds were able to germinate between 12.3 and $42.5^{\circ} \mathrm{C}$, but not at $45{ }^{\circ} \mathrm{C}$; the optimum temperature was $27{ }^{\circ} \mathrm{C}$. Imbibition at $45^{\circ} \mathrm{C}$ for $72 \mathrm{~h}$ was shown to cause irreversible damage to $M$. brauna seeds, impairing their germination, even when seeds were later transferred to $25^{\circ} \mathrm{C}$ (Santos et al., 2017). Radicle emergence depends not only on the growth potential of the embryo, but also on the reduction in mechanical resistance in the micropylar region (Bewley et al., 2013). Although the physical and biochemical aspects involved in this process are not fully understood, it is known that hydrogen peroxide production, hydrolases, and cellulases have an important role in weakening the cell wall (Zhang et al., 2014; Santos et al., 2017).

Enzyme activity was not observed in isolated micropyles imbibed for up to $72 \mathrm{~h}$. These results suggest that hydrolases and cellulases are produced in the embryonic axis and transferred to the micropylar region during germination, which reinforces the hypothesis that these enzymes contribute to radicle emergence by weakening the micropylar region.

Endo- $\beta$-mannanase activity was not detected under any of the evaluated conditions. Previous reports showed that its activity is intensified at the end of the germination process, mainly during seedling formation (Ferreira et al., 2018). The activity of all other enzymes differed significantly with temperature. $\alpha$-Gal activity was highest at 25 and $35{ }^{\circ} \mathrm{C}$ (Figure 2A). PG, PME and PL showed higher activities after $72 \mathrm{~h}$ of imbibition at $45^{\circ} \mathrm{C}$ (Figures 2B, 2C and 2D). These enzymes are crucial for cell wall degradation and radicle emergence (Borges et al., 2015; Bicalho et al., 2016).

$\alpha$-Gal activity depends on environmental conditions, including temperature (Coffigniez et al., 2018). In M. brauna seeds, the highest activity occurred at the optimal germination temperature $\left(25^{\circ} \mathrm{C}\right)$. In addition to metabolizing carbohydrate reserves, $\alpha$-Gal hydrolyzes cell wall polysaccharides and raffinose family oligosaccharides, thereby providing energy for germination (Bicalho et al., 2016; Farias et al., 2015). The low enzyme activity found at $45^{\circ} \mathrm{C}$ shows that $\alpha$-Gal is sensitive to heat stress. Similar to the observed in the current study, $\alpha$-Gal activity was highest at $25^{\circ} \mathrm{C}$ in Dalbergia nigra seeds (Ataíde et al., 2016).

PG is essential for the germination of Schizolobium parahyba and Arabidopsis sp. seeds (Magalhães et al., 2009; Han and Yang, 2015; Scheler et al., 2015). The enzyme catalyzes the hydrolysis of 1,4- $\alpha$-glycosidic bonds between galacturonic acid residues in the pectin chain. In the present study, PG activity was higher at $45{ }^{\circ} \mathrm{C}$ for all imbibition

Table 1. Germination percentage of Melanoxylon brauna seeds at different temperatures.

\begin{tabular}{cc}
\hline Temperature $(\stackrel{\circ}{ } \mathrm{C})$ & Germination (\%) \\
\hline 25 & $83 \mathrm{a}$ \\
35 & $55 \mathrm{~b}$ \\
45 & $0 \mathrm{c}$ \\
\hline
\end{tabular}

Means followed by different letters differ significantly by Tukey's test at $p<0.05$. 
times. The optimum germination temperature does not always coincide with the optimum temperature for enzyme activity. In D. nigra seeds, PG activity peaked at 40,45 and $60^{\circ} \mathrm{C}$, but germination percentage was highest at $25^{\circ} \mathrm{C}$ (Ataíde et al., 2016). In fruits of Uapaca kirkiana, Ziziphus mauritiana, Tamarindus indica and Berchemia, the optimum temperature range for PG activity was shown to be 25 to $37{ }^{\circ} \mathrm{C}$ (Muchuweti et al., 2005). In Prunus persica fruits, PG activity was highest during imbibition at $35^{\circ} \mathrm{C}$ (Sainz and Vendrusculo, 2015).

PME and PG have related functions. PME catalyzes the de-esterification of pectic substances by hydrolyzing methyl ester groups, producing pectin with a lower degree of methylation, which is then used as a substrate by PG (Sainz and Vendrusculo, 2015). PME activity increased after $24 \mathrm{~h}$ of imbibition at 25,35 and $45{ }^{\circ} \mathrm{C}$, but decreased after $48 \mathrm{~h}$ at $35^{\circ} \mathrm{C}$. At the basis of these results, it is possible to infer that the enzyme is produced before germination and is associated with the weakening of the seed coat and the degradation of the micropylar endosperm. These results agree with those obtained by Borges et al. (2015). The authors reported an increase in PME activity during imbibition of $M$. brauna seeds at $30^{\circ} \mathrm{C}$. PME activity was detected in Lepidium sativum seeds, suggesting that the enzyme plays an important role in testa rupture during radicle emergence (Scheler et al., 2015).

$\mathrm{PL}$ activity was highest at $45^{\circ} \mathrm{C}$ and increased with imbibition time at all temperatures. PL breaks down oligogalacturonides of the cell wall, deteriorating the lateral endosperm. The enzyme also induces the synthesis of expansins, which are mediators of the germination process (Zhao et al., 2008; Cao, 2012; Sainz and Vendrusculo, 2015).
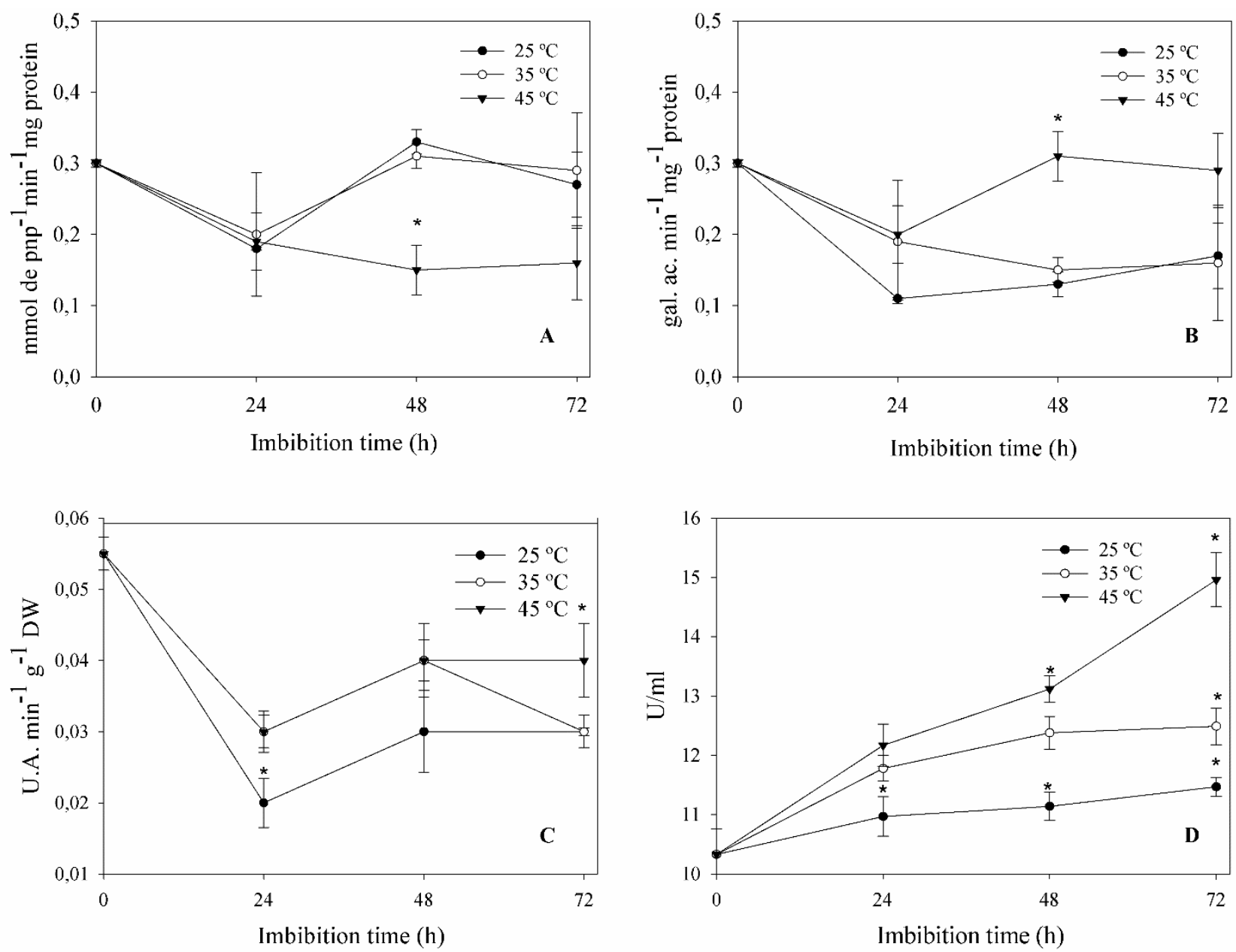

Asterisks $(*)$ indicate statistically significant differences between means. Vertical bars represent the standard error of the mean $(n=5)$.

Figure 2. $\alpha$-Galactosidase (A), polygalacturonase (B), pectin methylesterase (C) and pectin lyase (D) activities in the micropylar region of Melanoxylon brauna seeds during imbibition at 25,35 and $45^{\circ} \mathrm{C}$. 
Although hydrolases play a fundamental role in $M$. brauna seed germination, under heat stress $\left(45^{\circ} \mathrm{C}\right)$, high PG, PME and PL activities may contribute to seed deterioration. It is possible that an excessive increase in enzyme activity enhanced reserve degradation, accelerating the loss of cell wall integrity and increasing damage to cell membranes (Santos et al., 2017).

Total cellulase and $1,4-\beta$-glucosidase activities were highest at $35{ }^{\circ} \mathrm{C}$ after $48 \mathrm{~h}$ of imbibition (Figures $3 \mathrm{~A}$ and $3 \mathrm{C}$ ). This temperature also favored 1,3- $\beta$-glucosidase activity, which was found to increase with imbibition time (Figure 3B). At $45{ }^{\circ} \mathrm{C}, 1,3-\beta$ - and 1,4- $\beta$-glucosidase activities were lowest after $72 \mathrm{~h}$ of imbibition. This result is likely due to the loss
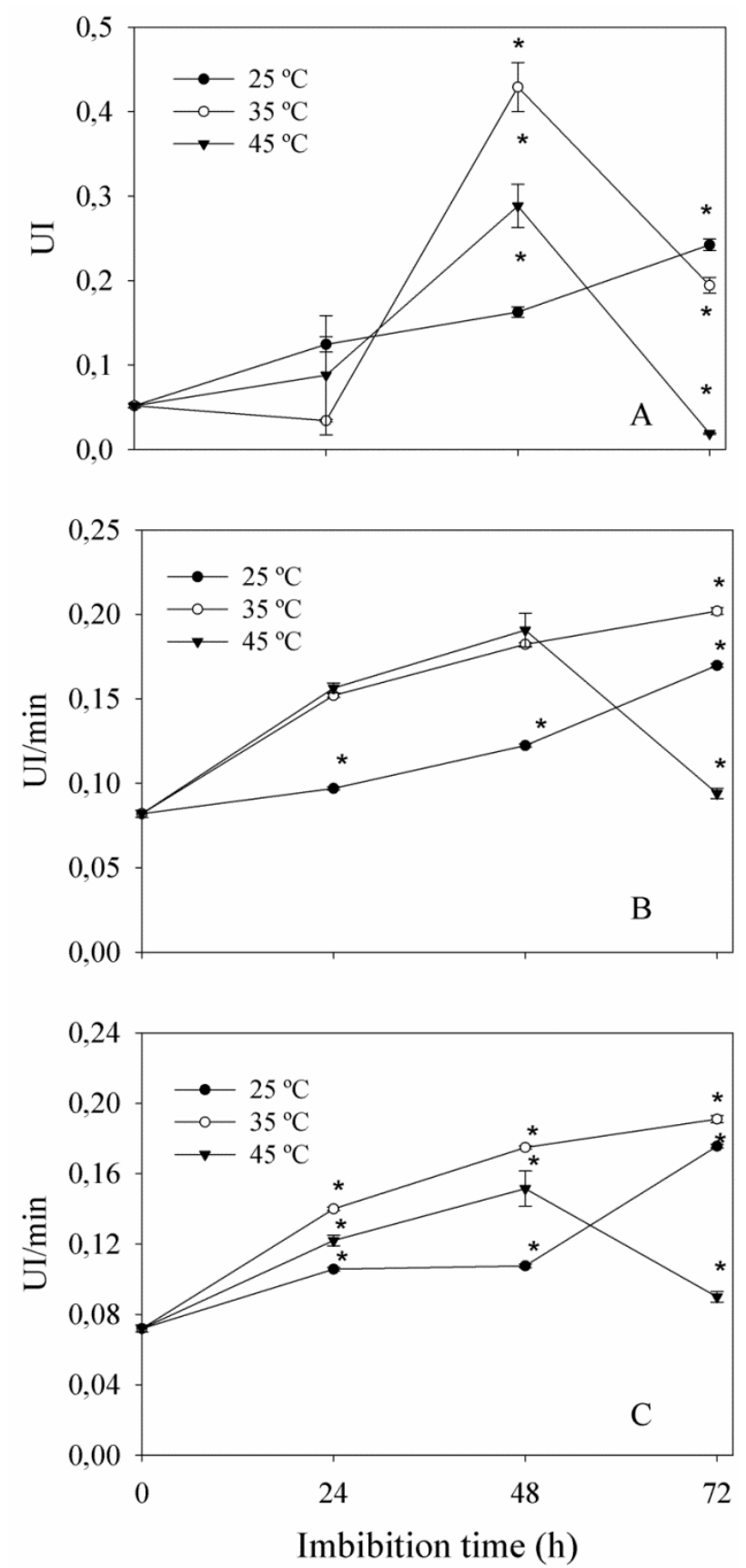

Asterisks $\left({ }^{*}\right)$ indicate statistically significant differences between means. Vertical bars represent the standard error of the mean $(n=5)$.

Figure 3. Total cellulase (A), 1,3- $\beta$-glucosidase (B) and 1,4- $\beta$-glucosidase (C) activities in the micropylar region of Melanoxylon brauna seeds during imbibition at 25,35 and $45^{\circ} \mathrm{C}$. 
of seed vigor caused by heat stress, resulting in protein denaturation and loss of enzyme activity (Santos et al., 2017). Cellulases are responsible for the degradation of cellulose, a major component of the plant cell wall. $\beta$-Glucosidases break the chemical bond between the glucose units of cellobiose, releasing free glucose. By doing so, they contribute to the weakening of the micropylar endosperm and provide energy for radicle emergence, as observed in seeds of Coffea arabica (Castro and Pereira, 2010), Lactuca sativa (Chen et al., 2016) and L. sativum (Ogórek, 2016).

Enzyme activity was related to germination percentage, but was less affected by high temperatures. The increase in enzyme activity in heat-stressed seeds probably contributed to cell wall degradation, leading to the accumulation of reactive oxygen species and membrane damage (Santos et al., 2017). The results show that PG, PME, PL, total cellulase, 1,3- $\beta$-glucosidase and 1,4- $\beta$-glucosidase activities can be used to assess the physiological quality of $M$. brauna seeds.

\section{CONCLUSIONS}

M. brauna seeds showed optimal germination at $25^{\circ} \mathrm{C}$. Imbibition at $45^{\circ} \mathrm{C}$ for $72 \mathrm{~h}$ resulted in the death of all seeds. Endo- $\beta$-mannanase activity was not detected after $72 \mathrm{~h}$ of imbibition at any of the tested temperatures. $\alpha$-Gal activity was highest after $48 \mathrm{~h}$ of imbibition at $25^{\circ} \mathrm{C}$ and lowest after $24 \mathrm{~h}$ at $45^{\circ} \mathrm{C}$. PG activity was highest after $48 \mathrm{~h}$ of imbibition at $45^{\circ} \mathrm{C}$ and lowest after imbibition at $25^{\circ} \mathrm{C}$. PME and PL activities increased during $72 \mathrm{~h}$ of imbibition at $45{ }^{\circ} \mathrm{C}$, but decreased during imbibition at $25^{\circ} \mathrm{C}$. Total cellulase, $1,3-\beta$-glucosidase, and $1,4-\beta$-glucosidase activities where highest during the first hours of imbibition at $45^{\circ} \mathrm{C}$, but decreased markedly after $48 \mathrm{~h}$. High PG, PME, PL, total cellulase, $1,3-\beta$-glucosidase and 1,4- $\beta$-glucosidase activities during imbibition indicate the occurrence of heat stress in M. brauna seeds.

\section{ACKNOWLEDGMENTS}

The authors thank the Coordenação de Aperfeiçoamento de Pessoal de Nível Superior (CAPES, Pró-Amazonas Project, no 52), the Conselho Nacional de Desenvolvimento Científico e Tecnológico (CNPq) and the Fundação de Amparo à Pesquisa do Estado de Minas Gerais (FAPEMIG) for their financial support.

\section{REFERENCES}

ALBERSHEIM, P.; DARVILL, A.G.; O'NEILL, M.A.; SCHOLS, H.A.; VORAGEN, A.G.J. An hypothesis: the same six polysaccharides are components of the primary cell walls of all higher plants. Progress in Biotechnology, v.14, p.47-55, 1996. https://doi.org/10.1016/ S0921-0423(96)80245-0

ALBERSHEIM, P.; KILIAS, U. Studies relating to the purification and properties of pectin transeliminase. Archives of Biochemistry and Biophysics, v.97, n.1, p.107-115, 1962. https://www.sciencedirect.com/science/article/pii/0003986162900504

ATAÍDE, G.M.; BORGES, E.E.L.; GONÇALVES, J.F.C.; GUIMARÃES, V.M.; FLORES, A.V. Alterações fisiológicas durante a hidratação de sementes de Dalbergia nigra ((Vell.) Fr. All. ex Benth.). Ciência Florestal, v.26, n.2, p.615-625, 2016. http://www.redalyc.org/ articulo.oa?id $=53446151024$

BETTS, N.S.; WILKINSON, L.G.; KHOR, S.F.; SHIRLEY, N.J.; LOK, F.; SKADHAUGE, B. Morphology, carbohydrate distribution, gene expression and enzymatic activities related to cell wall hydrolysis in four barley varieties during simulated malting. Frontiers in Plant Science, v.8, n.1872, 2017. https://www.frontiersin.org/articles/10.3389/fpls.2017.01872/full

BEWLEY, J.D.; BRADFORD, K.J.; HILHORST, H.W.M.; NONOGAKI, H. Seeds: physiology of development, germination and dormancy. New York: Springer, 2013.

BICALHO, E.M.; MOTOIKE, S.Y.; BORGES, E.E.L.; ATAÍDE, G.M.; GUIMARÃES, V.M. Enzyme activity and reserve mobilization during Macaw palm (Acrocomia aculeata) seed germination. Acta Botanica Brasilica, v.30, n.3, p.438-444, 2016. http://dx.doi. org/10.1590/0102-33062016abb0181 
BORGES, E.E.L.; ATAÍDE, G.M.; MATOS, A.C.B. Micropilar and embryonic events during hydration of Melanoxylon brauna Schott seeds. Journal of Seed Science, v.37, n.3, p.192-201, 2015. http://dx.doi.org/10.1590/2317-1545v37n3147846

BORGES, E.E.L.; REZENDE, S.T.; BORGES, R.C.G.; PEREZ, S.C.J.G.A. Caracterização de alfa-galactosidase em embrião e cotilédones de sementes de Platymiscium pubescens Micheli, var. pubecens (tamboril-da-mata). Revista Brasileira de Sementes, v.26, n.2, 2004. http://www.scielo.br/scielo.php?script=sci_arttext\&pid=S0101-31222004000200012\&lng=pt\&tlng=pt

BRADFORD, M.M. A rapid and sensitive method for the quantitation of microgram quantities of protein utilizing the principle of protein-dye binding. Analytical Biochemistry, v.72, n.1-2, p.248-254, 1976. https://doi.org/10.1016/0003-2697(76)90527-3

BRASIL. Ministério do Meio Ambiente. Instrução Normativa no 443, de 18 de setembro de 2014. Lista oficial das espécies da flora brasileira ameaçadas de extinção. <https://www.mma.gov.br/biodiversidade/conservacao-de-especies/fauna-ameacada/flora.html>.

CAO, J. The pectin lyases in Arabidopsis thaliana: evolution, selection and expression profiles. Plos One, v.7, n.10, 2012. https://doi. org/10.1371/journal.pone.0046944

CASTRO, A.M.; PEREIRA, J.R.N. Produção, propriedades e aplicação de celulases na hidrólise de resíduos agroindustriais. Química Nova, v.33, n.1, p.181-188, 2010. http://submission.quimicanova.sbq.org.br/qn/qnol/2010/vol33n1/30-RV09352.pdf

CHEN, B.; MA, J.; XU, Z.; WANG, X. Abscisic acid and ethephon regulation of cellulase in the endosperm cap and radicle during lettuce seed germination. Journal of Integrative Plant Biology, v.58, n.10, p.859-869, 2016. https://onlinelibrary.wiley.com/doi/ epdf/10.1111/jipb.12479

COFFIGNIEZ, F.; BRIFFAZ, A.; MESTRES, C.; RICCI, J.; ALTER, P.; DURAND, N.; BOHUON, P. Kinetic study of enzymatic $\alpha$-galactoside hydrolysis in cowpea seeds. Food Research International, v.113, p.443-451, 2018. DOI10.1016/j.foodres.2018.07.030

DOWNIE, B.; HILHORST, H.; BEWLEY, J.D. A new assay for quantifying endo- $\beta$-mananase activity using congo red dye. Phytochemistry, v.36, n.4, p.829-835, 1994. https://www.sciencedirect.com/science/article/pii/S0031942200904461

FARIAS, E.T; SILVA, E.A.A.; TOOROP, P.E.; BEWLEY, J.D.; HILHORST, H.M. Expression studies in the embryo and in the micropylar endosperm of germinating coffee (Coffea arabica cv. Rubi) seeds. Plant Growth Regulation, v.75, n.2, p.575-581, 2015. https:// link.springer.com/article/10.1007/s10725-014-9960-6

FERREIRA, V.F.; RICALDONI, M.A.; ROSA, S.V.B.; FANTASINI, T.B. Endo- $\beta$-mannanase enzyme activity in the structures of Coffea arabica L. seeds under different types of processing and drying. Ciência Rural, v.48, n.12, 2018. https://dx.doi.org/10.1590/01038478 cr20170839

FLORES, A.V.; BORGES, E.E.L.; GUIMARÃES, V.M.; ATAÍDE, G.M.; CASTRO, R.V.O. Germinação de sementes de Melanoxylon brauna Schott em diferentes temperaturas. Revista Árvore, v.38, n.6, p.1147-1154. 2014. http://www.scielo.br/scielo.php?script=sci_ arttext\&pid=S0100-67622014000600019

GHOSE, T.K. Measurement of cellulase activities. Pure and Applied Chemistry, v.59, n.2, p.257-268, 1987. https://doi.org/10.1351/ pac198759020257

GRAEBER, K.; LINKIES, A.; STEINBRECHER, T.; MUMMENHOFF, K.; TARKOWSKA, D.; TURECKOVA, V.; IGNATZ, M.; SPERBER, K.; VEOGELE, A.; JONG; H.; URBANOVÁ, T.; STRNAD, M.; LEUBNER-METZGER, G. Delay of germination mediates a conserved coatdormancy mechanism for the temperature- and gibberellin-dependent control of seed germination. Proceedings of the National Academy of Sciences, v.111, n.34, p.3571-3580, 2014. https://doi.org/10.1073/pnas.1403851111

GRSIC-RAUCH, S.; RAUSCH, T. A coupled spectrophotometric enzyme assay for the determination of pectin methylesterase activity and its inhibition by proteinaceous inhibitors. Analytical Biochemistry, v.333, n.1, p.14-18, 2004. https://doi.org/10.1016/j. ab.2004.04.042

HAN, C.; YANG, P. Studies on the molecular mechanisms of seed germination. Proteomics, v.15, p.1671-1679, 2015. https:// onlinelibrary.wiley.com/doi/epdf/10.1002/pmic.201400375

KOEN, J.; SLABBERT, M.M.; BESTER, C.; BIERMAN, F. Germination characteristics of dimorphic honeybush (Cyclopia spp.) seed. South African Journal of Botany, v.110, p.68-74, 2017. https://doi.org/10.1016/j.sajb.2016.03.006

LAGHMOUCHI, Y.; BELMEHDI, O.; BOUYAHYA, A.; SENHAJI, N.S.; ABRIN, J. Effect of temperature, salt stress and pH on seed germination of medicinal plant Origanum compactum. Biocatalysis and Agricultural Biotechnology, v.10, p.156-160, 2017. https:// doi.org/10.1016/j.bcab.2017.03.002

Journal of Seed Science, v.42, e202042009, 2020 
LORENZI, H. Árvores brasileiras: manual de identificação e cultivo de plantas arbóreas nativas do Brasil. Nova Odessa: Instituto Platarum, 2008.

MAGALHÃES, S.M.; BORGES, E.E.L.; BERGER, A.P. Alterações nas atividades das enzimas alfa-galactosidade e poligalacturonase e nas reservas de carboidratos de sementes de Schizolobium parahyba (vell.) Blake (guapuruvú) durante a germinação. Revista Brasileira de Sementes, v.31, n.2, p.253-261, 2009. http://www.scielo.br/scielo.php?pid=S0101-31222009000200030\&script=sci_ abstract\&tlng=pt

MASCHER, M.; GUNDLACH, H.; HIMMELBACH, A.; BEIER, S.; TWARDZIOK, S.; WICKER, T. A chromosome conformation capture ordered sequence of the barley genome. Nature, v.544, p.427-433, 2017. https://www.nature.com/articles/nature22043

MEDINA, C.V.; RODRIGUEZ, E.A.G.; BAGANTIM, A.G.; ANDRADE, R.A. Temperatura e armazenamento na germinação de sementes de Mabolo (Diospyros blancoi Willd). Nucleus, v.13, n.1, 2016. http://dx.doi.org/10.3738/1982.2278.1538

MILLER G.L. Use of dinitrosalicylic acid reagent for determination of reducing sugar. Analytical Chemistry, v.31, n.3, p.426-428, 1959. https://pubs.acs.org/doi/abs/10.1021/ac60147a030

MUCHUWETI, M.; MOYO, E.; MUSHIPE, S. Some properties of the polygalacturonase from four Zimbabwean wild fruits (Uapaca kirkiana, Ziziphus mauritiana, Tamarindus indica and Berchemia discolor fruits). Food Chemistry, v.90, n.4, p.655-661, 2005. https:// www.sciencedirect.com/science/article/pii/S0308814604003784?via\%3Dihub

NONOGAKI, H.; BASSEL, G.W.; BEWLEY, J.D. Germination: still a mystery. Plant Science, v.179, n.6, p.574-581, 2010. https://doi. org/10.1016/j.plantsci.2010.02.010

OGÓREK, R. Enzymatic activity of potential fungal plant pathogens and the effect of their culture filtrates on seed germination and seedling growth of garden cress (Lepidium sativum L.). European Journal of Plant Pathology, v.145, n.2, p.469-481, 2016. https:// link.springer.com/article/10.1007/s10658-016-0860-7

OLIVEIRA, F.N.; FRANÇA, F.D.; TORRES, S.B.; NOGUEIRA, N.W.; FREITAS, R.M.O. Temperaturas e substratos na germinação de sementes de pereiro-vermelho (Simira gardneriana M.R. Barbosa \& Peixoto). Revista Ciência Agronômica, v.47, n.4, p.658-666, 2016. http://dx.doi.org/10.5935/1806-6690.20160079

PINTO, L.K.A.; MARTINS, M.L.L.; RESENDE, E.D.; THIEBAUT, J.T.L. Atividade de pectina metilesterase e da $\beta$-galactosidase durante o amadurecimento do mamão cv. Golden. Revista Brasileira de Fruticultura, v.33, n.3, p.713-722, 2011. http://www.scielo.br/scielo. php?pid=S0100-29452011000300004\&script=sci_abstract\&tlng=pt

PBMC. Painel Brasileiro de Mudanças Climáticas. Contribuição do grupo de trabalho 2 ao primeiro relatório de avaliação nacional do painel brasileiro de mudanças climáticas: sumário executivo. Rio de Janeiro, RJ, Brasil: PBMC, 2013. 28p. http://www.pbmc. coppe.ufrj.br/documentos/MCTI_PBMC_sumario_executivo_impactos_vulnerabilidades_e_adaptacao_WEB_3.pdf

SAINZ, R.L.; VENDRUSCULO, J.L.S. Propriedade da poligalacturonase e pectinametilesterase em pêssego (Prunus persica (L.) Batsch) de cultivares brasileiras. Revista Brasileira de Tecnologia Agroindustrial, v.9, n.1, p.1724-1743, 2015. https://periodicos.utfpr.edu.br/rbta/ article/view/2403

SANTOS, M.M.; BORGES, E.E.L.; ATAÍDE, M.M.; SOUZA, G.A. Germination of seeds of Melanoxylon brauna Schott. under heat stress: production of reactive oxygen species and antioxidant activity. Forests, v.8, n.11, p.405, 2017. https://www.mdpi.com/1999$4907 / 8 / 11 / 405$

SCHELER, C.; WEITBRECTHT, K.; PEARCE, S.P.; HAMPSTEAD, A.; BUTTNER-MAINIK, A.; LEE, K.J.D.; VOEGELE, A.; ORACZ, K.; BAS, J.W.; WANG, X.F.; WOOD, A.T.A.; BENTSINK, L.; KING, J.R.; KNOX, P.; HOLDSWORTH, M.J.; MULLER, K.; LEUBNER-METZGER, G. Promotion of testa rupture during garden cress germination involves seed compartment-specific expression and activity of pectin methylesterase. Plant Physiology, v.167, p.200-215, 2015. http://www.plantphysiol.org/content/plantphysiol/167/1/200.full.pdf

SILVA, M.L.M.; ALVES, E.U.; BRUNO, R.L.L.; SANTOS-MOURA, S.S.; SANTOS-NETO, A.P. Germinação de sementes de Chorisia glaziovii O. Kuntze submetidas ao estresse hídrico sob diferentes temperaturas. Ciência Florestal, v.26, n.3, p.999-1007, 2016. https://www. redalyc.org/pdf/534/53447685028.pdf

SINGH, V.P.; SINGH, S.; TRIPATHI, D.K.; PRASAD, S.M.; CHAUHAN, D.K. Reactive oxygen species in plants. John Wiley \& Sons: Nova Jersey, 2017.

SINGHANIA, R.R.; PATEL, A.K.; SUKUMARAN, R.K.; LARROCHE, C.; PANDEY, A. Role and significance of beta-glucosidases in the 
hydrolysis of cellulose for bioethanol production. Bioresource Technology, v.127, p.500-507, 2013. https://doi.org/10.1016/j. biortech.2012.09.012

YAN, D.; DUERMEYER, L.; LEOVEANU, C.; NAMBARA, E. The functions of the endosperm during seed germination. Plant and Cell Physiology, v.55, n.9, p.1521-1533, 2014. https://doi.org/10.1093/pcp/pcu089

ZHANG, Y.; CHEN, B.; XU, Z.; SHI, Z.; CHEN, S.; HUANG, X.; CHEN, J.; WANG, X.F. Involvement of reactive oxygen species in endosperm cap weakening and embryo elongation growth during lettuce seed germination. Journal of Experimental Botany, v.65, n.12, p.31893200, 2014. https://doi.org/10.1093/jxb/eru167

ZHAO, Q.; YUAN, S.; WANG, X.; ZHANG, Y.; ZHU, H. Restoration of mature etiolated cucumber hypocotyl cell wall susceptibility to expansin by pretreatment with fungal pectinases and EGTA in vitro. Plant Physiology, v.147, p.1874-1885, 2008. http://www. plantphysiol.org/content/plantphysiol/147/4/1874.full.pdf use, distribution, and reproduction in any medium, provided the original work is properly cited. 